\title{
Talking about Color and Taste on the Trobriand Islands: A Diachronic Study
}

\section{Gunter Senft}

ABSTRACT How stable is the lexicon for perceptual experiences? This article presents results on how the Trobriand Islanders of Papua New Guinea talk about color and taste and whether this has changed over the years. Comparing the results of research on color terms conducted in 1983 with data collected in 2008 revealed that many English color terms have been integrated into the Kilivila lexicon. Members of the younger generation with school education have been the agents of this language change. However, today not all English color terms are produced correctly according to English lexical semantics. The traditional Kilivila color terms bwabwau 'black,' pupwakau 'white,' and bweyani 'red' are not affected by this change, probably because of the cultural importance of the art of coloring
Gunter Senft is a Senior Research Fellow at the Max Planck Institute for Psycholinguistics, The Netherlands, and Extraordinary Professor of General Linguistics at the University of Cologne, Germany. gunter.senft@mpi.nl 
canoes, big yams houses, and bodies. Comparing the 1983 data on taste vocabulary with the results of my 2008 research revealed no substantial change. The conservatism of the Trobriand Islanders' taste vocabulary may be related to the conservatism of their palate. Moreover, they are more interested in displaying and exchanging food than in savoring it. Although English color terms are integrated into the lexicon, Kilivila provides evidence that traditional terms used for talking about color and terms used to refer to tastes have remained stable over time.

KEYWORDS: color, taste, language of perception, Kilivila, semantic categories

\section{Introduction}

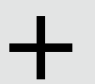

This article addresses the question: how stable is the lexicon for perceptual experiences? I started my field research on the Trobriand Islands in Papua New Guinea in 1982. In 1982-3 I collected data on Kilivila color and taste terms. In an article on color terms (Senft 1987) I made a number of predictions with respect to the direction of the language change which I observed in 1983. In 2008 I continued my fieldwork on the Trobriands with the aim of researching the Trobrianders' language of perception. I was very much interested in finding out whether this research could verify my predictions with respect to changes in the Kilivila color lexicon, and I also wanted to see whether I could observe such changes in other perceptual domains. I knew that the Trobrianders are very conservative with respect to their ways of cooking; therefore, I decided to have a closer look at the Kilivila lexicon for taste and flavor. This article compares my 1983 results with my 2008 data on how the Trobriand Islanders talk about color and taste.

The Trobriand Islanders are best known through the works of Bronislaw Malinowski, who did field research among them between 1916 and 1920. The Trobrianders belong to the ethnic group called Northern Massim. They tend gardens and raise pigs. Moreover, they are famous for being excellent canoe builders, carvers, and navigators, especially in connection with the ritualized Kula trade, an exchange of shell valuables that covers a wide area of the Melanesian part of the Pacific. The society is matrilinear but virilocal.

The Trobriand Islanders' language Kilivila is one of forty Austronesian languages spoken in the Milne Bay Province of Papua New Guinea. The Austronesian languages spoken in this area are grouped into twelve language families; one of them is labeled Kilivila. The Kilivila language family encompasses the languages Budibud, Muyuw, and Kilivila. Kilivila is a Western Melanesian Oceanic language belonging to the Papuan-Tip-Cluster group (Senft 1986: 6). 


\section{Kilivila Color Terms in 1983 and in 2008}

In 1983 I collected data on color terms with sixty consultants representing five generations (ranging from four to seventy-five years of age). To elicit terms I used the color plate in Pheby and Scholze (1979: 600f. [plate 343]). Aims, methods, and results of this study are reported in Senft (1987). Here is a brief summary of the main findings.

The generic term for 'color' is noku. My consultants produced four categories of terms as a reaction to the color stimuli white, black, red, yellow, green, blue, brown, azure/sky blue, orange, pink and violet:

1. Abstract terms, i.e. "basic color terms" in Berlin and Kay's (1969) sense.

2. Source terms referring to plants, trees, fruits, etc. for example digadegila 'yellow,' veravera 'pink,' and source terms like kwinin 'yellow,' which refers to quinine, a drug against malaria (the tablets were yellow), and budakola 'charcoal.' These terms were rarely used.

3. Loan words, i.e. color terms borrowed from English, transformed and produced in the mold of Kilivila word formation principles like bulum 'blue, azure, green,' pepol 'purple,' and kwegulini 'green.' 4. English color terms.

The general picture with respect to the 1983 inventory and usage of Kilivila color terms is as follows: pupwakau 'white,' bwabwau 'black,' bweyani 'red,' kwinin 'yellow,' and digadegila 'yellow' were used by all consultants. The majority of the consultants used English color terms that refer to these colors correctly. Schoolchildren (ranging from eight to fourteen years of age) expanded their color term lexicon producing the English terms green, blue, brown, purple, pink, and orange.

In 1983 I predicted that schoolchildren would continue expanding the inventory of Kilivila color terms by integrating more and more English terms into the Kilivila lexicon, that this process would supersede the use of English loan words (that is the term blue, for example, will supersede the loan form bulum), and that source terms would probably no longer be used to refer to colors. To test this prediction, in 2008 I elicited data from twelve consultants using the Color Kit described in Majid and Levinson (this issue; see Majid 2007). This color kit is a booklet with eighty pages, each page containing a single color chip. It uses standardized Munsell colors ${ }^{2}$ which samples twenty equally spaced hues at four degrees of brightness. The chips are organized in a fixed random order. Consultants were first tested for color blindness; then they were presented with the color booklet pages and asked What color is this? The Kilivila equivalent of this question is: Amyagala manakwa noku? 'What's the name of this color?' I worked with five female and 
seven male consultants ranging in age from fifteen to sixty-five years. Two men and two women had learned English at primary school; one man and one woman had learned English at the Kiriwina High School.

The 2008 study revealed that there are gaps in the Kilivila color lexicon: none of the twelve consultants could produce names for all the color stimuli presented. English color terms are obviously produced to fill such gaps ${ }^{3}$; however, not all English color terms are produced correctly according to English lexical semantics (so far I cannot not find any explanation for why these terms are incorrectly produced). The language change observed in 1983 is still in progress.

Traditional abstract color terms pupwakau 'white,' bwabwau 'black,' and bweyani 'red' are still produced to refer to a relatively broad range of color stimuli. Three younger consultants did not produce these three terms at all during the data elicitation session; instead, they produced the equivalent English color terms. However, when asked whether they always use black, white, and red, they emphasized that they use the equivalent Kilivila color terms to refer to objects in their material culture that are painted with these colors (like canoes, chiefly yams houses, body paintings, etc.). That means that the terms pubwakau, bwabwau, bweyani and the terms white, black, and red are used in different contexts. Thus, traditional abstract Kilivila color terms are not affected by the language change in progress. It is as if the utilization of the traditional terms were somehow insulated in the same way that the circulation of certain traditional valuables - namely the famous Kula armshells and necklaces - remains insulated from market exchange. Such items are not for purchase and only figure in the endless round of ceremonial exchange known as the Kula ring.

The source terms kwinin and digadegila are being superseded by the English term yellow. However, the use of other source terms (that refer to trees, blossoms, flowers, etc.) can still be observed with all consultants. Terms produced were: semtamata 'green,' dararugu 'purple,' gana'ugwa 'red,' veravera 'pink' soso'u 'red' botova 'brown,' and oravera 'pink.' Thus, contrary to my prediction, these terms are still used to refer to colors.

Only two consultants produced the loan word kwegulini 'green'; as predicted, loan words are superseded by English color terms. The terms green, blue, brown, orange, purple, and pink are integrated into the Kilivila lexicon. Moreover, half of the consultants start to differentiate colors adding the modifiers 'dark' and 'light'; however, it may be that the speakers hedge their insecurity about knowledge of the English terms with this differentiation.

Consultants were not consistent in the use of color terms. The majority of speakers who used English terms belong to the younger generation with school education; they are still the agents of the language change in progress affecting the Kilivila lexicon. 
Why do we observe stability as well as change in the Kilivila color term lexicon? On the one hand, the fact that the traditional Kilivila terms that refer to the colors 'black,' 'white,' and 'red' - bwabwau, pubwakau, and bweyani - are still produced by all Trobriand Islanders seems to mirror the importance of the art of coloring canoes, the Malasi chiefs' big yams houses, bodies, etc. On the other hand, learning English at school is the most important reason why the Kilivila color term lexicon has been changing over the last years. In addition, globalization, especially changes in clothing style (with very colorful clothes) and in dyeing traditional grass skirts (with a variety of new chemical dyes) play an important role in stimulating this language change. This illustrates the strong interdependence between language (change) and culture (change).

\section{Pacific Islanders Talking about Taste Then and Now}

In 1982-3 I collected the following taste terms:

sumakenia - 'sweet, rich, tasty'

payuyu - 'sour, bitter, unripe'

yayana/yayani - 'bitter, hot, harsh'

yona - 'salt, salty, saltwater'

Terms referring to flavors were:

$$
\begin{aligned}
& \text { bolova - 'stale, insipid' } \\
& \text { gegeda - 'biting, hurting' } \\
& \text { gasisi - 'fierce, wild, terrible, bad' }
\end{aligned}
$$

Moreover, the words bwena 'good' and gaga 'bad' were also used to refer to tastes. All these terms were not specifically elicited, but used by my consultants in everyday speech, stories, and other text categories.

In 2008 my interest in the Trobriand Islanders' language of perception included the focused investigation of how Kilivila encodes taste experiences. I wanted to know whether there is a more comprehensive vocabulary for encoding taste than the vocabulary I had already documented and whether taste terms are also affected by language change.

I elicited data with four female and eight male consultants ranging in age from twenty-five to seventy-two years. One woman had some years of primary school experience and spoke some English.

Bartoshuk (1978: 5) emphasizes that the so-called four "basic tastes" - sweet, bitter, sour, salty - have played a crucial role from the very beginning of taste research, which goes back to Aristotle. As Lawless (2001: 616f.) points out, the Japanese word umami 'delicious taste' was proposed in more recent research as another basic taste. In the current study these five taste qualities were investigated. To elicit the data the Taste Kit described in Majid and Levinson was used (this issue; see Majid 2007). ${ }^{4}$ 
There were four $100 \mathrm{ml}$ solutions, one for sweet (10 percent), sour (5 percent), bitter (0.05 percent), and salty (7.5 percent), and granules of glutamate were used (umami). Each solution was sprayed onto the consultant's tongue. After every taste experience, consultants had to rinse their mouth with water. Before and after I sprayed the solutions onto their tongues I asked my consultants the following two questions: Amakala kamwenala? 'How does it taste?' and Avaka kamwenala makala? 'What is this taste like?'

The consultants produced the following taste and flavor terms: (1) six abstract terms - bolova 'tasteless, stale,' gegeda 'hot,' payuyu 'sour,' sumakenia 'sweet,' tumwaka 'brackish,'5 yayana/yayani 'bitter, salty (?)'; (2) two descriptive generally evaluative terms: bwena 'good,' gaga 'bad,' and (3) two source terms: solot 'salt' and yona 'salt water, salt, salty.'

There is another descriptive term to refer to a hot flavor, gasisi (which also means 'fierce'), but this term was not produced during this study. A few source terms that refer to fruits having a specific taste were also produced - though rather rarely. The English loan word solot was produced by one consultant; and two informants produced as a reaction to the umami stimulus the loan word nudusi 'noodles' - referring to a Maggi noodle soup (which is sold in the stores on Kiriwina Island with a separate packet of glutamate within the bigger soup packet). ${ }^{6}$

The term sumakenia was used by all consultants to refer to a sweet taste. The term yona was used by all and the term yayana/ yayani by two thirds of the consultants to refer to the salty taste. Nine consultants used the term yayana/yayani to refer to the bitter taste. Ten consultants used the term payuyu to refer to the sour taste. The Trobrianders have no dedicated term that they can use to refer to the umami taste.

Comparing these results with the lexical entries in my dictionary (Senft 1986) we observe almost no change at all. The only new insight we get is that the term yayana/yayani, which is used to refer to the bitter taste, competes with the term yona to refer to the salty taste. Moreover, it turned out that the flavor terms gegeda and gasisi should also be glossed as 'hot' (with respect to a spicy flavor; the latter term was not produced by consultants in my 2008 study). Thus we can conclude that there is great stability in the Kilivila taste lexicon with hardly any influence from English. The conservatism of the Trobriand Islanders' taste vocabulary may be related to the conservatism of their palate. There is very little variety in their daily diet, which consists of cooked yams, taro, sweet potatoes, greens, fish and other seafood, and very occasionally a piece of pork. Yams, taro, and sweet potatoes are scraped and boiled in a pot of water that just contains a cup of salt water; greens are boiled in the same way. Small chilies and other spices grow in the bush, but only very few women use them to spice their food. Although globalization has reached the 
Trobriands, hardly any effects of this get reflected in the Islanders' taste vocabulary. ${ }^{7}$

Malinowski (1929: 371f.) already pointed out that the Trobriand Islanders have a specific relationship to food and eating:

Eating is not regarded as indispensable to life, nor is the value of food as a utility recognized and formulated by the natives ... they have no idea that there is such a thing as a physiological need for alimentation.

The Trobrianders value food not for consumption, but as an important and absolutely necessary component for exchange rituals of all kinds. It would appear that for the Trobriander it is considered better to give food to others than to eat it oneself, because giving is the path to fame or "noise" (butu), and Trobrianders generally attach greater cultural importance to being heard and/or talked about than to enjoying a full belly (see Howes 2003: Ch. 3).

\section{Concluding Remarks}

This case study of Kilivila color and taste terms suggests that the sensory vocabularies in question have remained fairly stable over time. Members of the younger generation with school education have managed to expand the Kilivila inventory of color terms by integrating English color terms into the Kilivila lexicon. But speakers still produce traditional abstract Kilivila color terms; they use the respective English color terms, too, albeit in different contexts. English color terms have neither superseded traditional color terms nor most of the source terms used to refer to colors. In the Kilivila taste lexicon we observe great stability; it has not been affected by any kind of language change. These results are amazing if we look at the many dramatic changes I have been observing in the Trobriand Islanders' language and culture over the last twenty-five years (Senft 1992). ${ }^{8}$

\section{Acknowledgments}

This study was carried out as part of the Language of Perception study within the Categories across Language and Cognition project at the Max Planck Institute for Psycholinguistics. I want to thank the National and Provincial Governments in Papua New Guinea, the Institute for PNG Studies and the National Research Institute for their assistance with, and permission for, my research. I express my great gratitude to the people of the Trobriand Islands, especially to the inhabitants of Tauwema for their hospitality, friendship, and patient cooperation over all these years.

\section{Notes}

1. Bulum and kwegulini are borrowed from English, but transformed into the mold of a Kilivila word by regular word formation 
principles: bulum agrees with the syllable structure (Consonant)Vowel $(\$(C) \vee \$)$ and the fact that $/ \mathrm{m} /$ can be syllabic; kwegulini consists of the general classifier kwe- and the loan word for 'green,' which follows Kilivila syllable structure rules.

2. Munsell color chips were also used by Berlin and Kay (1969) and in later studies (see e.g. Kay and Regier 2006).

3. Further research is needed here.

4. I thank Ulrich Schlotmann for professional support in putting together the Taste Kit.

5. This term escaped my attention in 1982-3.

6. This neologism nicely illustrates that speakers are highly opportunistic in their choice of terms for referring to things that are new for them. One of the anonymous referees rightly points out that nudusi "is not a taste category, it is a commodity."

7. I would like to point out that taste terms are not taught at school in the same way that color (and shape) terms are. I also would like to add that globalization does not affect their "cuisine" - despite the noodles that are sold in the stores on Kiriwna Island.

8. I would like to thank David Howes for insightful comments on an earlier draft of this article

\section{References}

Bartoshuk, Linda M. 1978. "History of Taste Research." In Edward C. Carterette and Morton P. Friedman (eds), Handbook of Perception Volume VIA: Tasting and Smelling. New York: Academic Press.

Berlin, Brent and Kay, Paul. 1969. Basic Color Terms: Their Universality and Evolution. Berkeley, CA: University of California Press.

Howes, David. 2003. Sensual Relations. Engaging the Senses in Culture and Social Theory. Ann Arbor, Ml: University of Michigan Press.

Kay, Paul and Regier, Terry. 2006. "Language, Thought, and Color: Recent Developments." Trends in Cognitive Sciences 10(2): 51-4. Lawless, Harry T. 2001. "Taste." In E. Bruce Goldstein (ed.), Blackwell Handbook of Perception, pp. 601-35. Oxford: Blackwell Publishers.

Majid, Asifa (ed.). 2007. Field Manual, Vol. 10. Nijmegen: Max Planck Institute for Psycholinguistics.

Malinowski, Bronislaw. 1929. The Sexual Life of Savages in NorthWestern Melanesia. New York: Harcourt, Brace and World.

Pheby John and Scholze, Werner (eds). 1979. Oxford-Duden Bildwörterbuch Deutsch und Englisch. Mannheim: Bibliographisches Institut.

Senft, Gunter. 1986. Kilivila: The Language of the Trobriand Islanders. Berlin: Mouton de Gruyter.

Senft, Gunter. 1987. "Kilivila Color Terms." Studies in Language 11(2): 315-46. 
Senft, Gunter. 1992. "'As Time Goes By...': Changes Observed in Trobriand Islanders' Culture and Language, Milne Bay Province, Papua New Guinea." In Thomas Dutton (ed.), Culture Change, Language Change: Case Studies from Melanesia, pp. 67-89. Canberra: Pacific Linguistics. 